
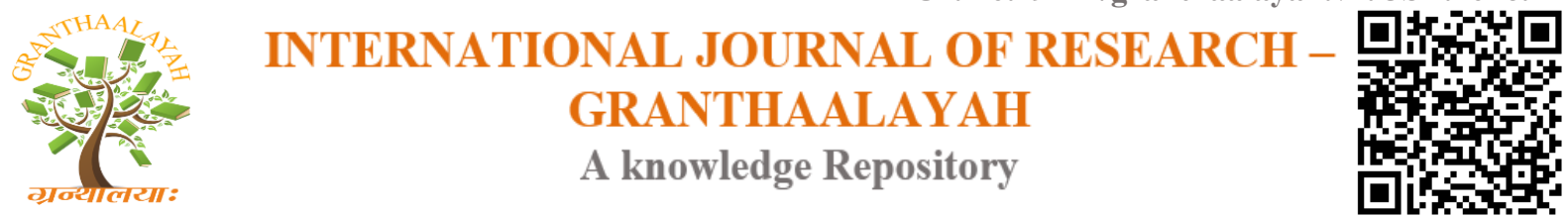

Management

\title{
ADVANTAGES AND CHALLENGES OF E-COMMERCE CUSTOMERS AND BUSINESSES: IN INDIAN PERSPECTIVE
}

\author{
Dr. C. Eugine Franco ${ }^{* 1}$, Bulomine Regi. $\mathrm{S}^{2}$ \\ ${ }^{* 1}$ HOD of Commerce, St. Xavier's College (Autonomous), Palayamkottai, INDIA \\ ${ }^{2}$ Ph.D Research Scholar (FT), Commerce Research Center, St. Xavier's College (Autonomous), \\ Palayamkottai, INDIA
}

\begin{abstract}
E - Commerce allows consumers to electronically exchange goods and services with no barriers of time or distance. Electronic commerce has expanded rapidly over the past five years and is predicted to continue at this rate, or even accelerate. In the near future the boundaries between "conventional" and "electronic" commerce will become increasingly blurred as more and more businesses move sections of their operations onto the Internet. The e-commerce industry in India is growing at a remarkable pace due to high penetration of internet and sophisticated electronic devices. However, the recent growth rate of e-commerce in India is far lagging behind than other developed countries. The advantages of e-commerce are convenience, Time saving, Options, Easy to compare, Easy to find reviews, Coupons and deals, Increasing customer base, Rise in sales, 24/7, 365 days, Expand business reach, Recurring payments made easy, Instant transactions. There are many big problems and challenged on the way of an online merchant. Factors like safety and security of online money transaction being the biggest problem along with others have curbed the smooth expansion of the online industry in the country.
\end{abstract}

Keywords:

e-commerce, electronic commerce, advantages, challenges.

Cite This Article: Dr. C. Eugine Franco, and Bulomine Regi. S, "ADVANTAGES AND CHALLENGES OF E-COMMERCE CUSTOMERS AND BUSINESSES: IN INDIAN PERSPECTIVE" International Journal of Research - Granthaalayah, Vol. 4, No. 3: SE (2016): 7-13.

\section{INTRODUCTION}

Electronic commerce or ecommerce is a term for any type of business, or commercial transaction, which involves the transfer of information across the Internet. It covers a range of different types of businesses, from consumer based retail sites, through auction or music sites, to business exchanges trading goods and services between corporations. It is currently one of the most important aspects of the Internet to emerge. Ecommerce allows consumers to electronically 
exchange goods and services with no barriers of time or distance. Electronic commerce has expanded rapidly over the past five years and is predicted to continue at this rate, or even accelerate. In the near future the boundaries between "conventional" and "electronic" commerce will become increasingly blurred as more and more businesses move sections of their operations onto the Internet.

Business to Business or $\mathrm{B} 2 \mathrm{~B}$ refers to electronic commerce between businesses rather than between a business and a consumer. B2B businesses often deal with hundreds or even thousands of other businesses, either as customers or suppliers. Carrying out these transactions electronically provides vast competitive advantages over traditional methods. When implemented properly, ecommerce is often faster, cheaper and more convenient than the traditional methods of bartering goods and services. Electronic transactions have been around for quite some time in the form of Electronic Data Interchange or EDI. EDI requires each supplier and customer to set up a dedicated data link (between them), where ecommerce provides a costeffective method for companies to set up multiple, ad-hoc links. Electronic commerce has also led to the development of electronic marketplaces where suppliers and potential customers are brought together to conduct mutually beneficial trade.

\section{E-COMMERCE ADVANTAGES FOR CUSTOMERS}

Convenience: Every product is at the tip of your fingers on the internet, literally. Type in the product you are looking for into your favorite search engine and every option will appear in a well-organized list in a matter of seconds.

Time saving: With e-commerce there is no driving in circles while looking and digging in hopes of finding what you need. Stores online offer their full line as well as use warehouses instead of store fronts_- products are easy to locate and can be delivered to your door in just days.

Options, options, and options: Without driving from store to store the consumer can easily compare and contrast products. See who offers the best pricing and have more options to choose from. While a physical store has limited space, the same store on the internet will have full stock.

Easy to compare: Side by side comparisons are readily available and easy to do. When products are placed online, they come with all the specifics, and they want you to compare them with others, know they have the best options and come back for more!

Easy to find reviews: Because the competition is high, companies' online want you to look at other consumer reviews. Good and bad reviews are on every site, not only can you see if the product is liked, you can also see the reasons behind the thumbs up or down.

Coupons and deals: With every online business wanting you, more and more coupons and deals can't be avoided, which are totally great for customers. With major sites that act as department store, you may find items up to $80 \%$ off. Take advantage of the competition and find the best price available. 


\section{E-COMMERCE ADVANTAGES FOR BUSINESSES}

Increasing customer base: The customer base is every business's main concern, online or off. When online, a business doesn't have to worry about getting the best property in town, people from around the world have access to their products and can come back at any time.

Rise in sales: By not managing a storefront, any business will have more sales online with a higher profit margin. They can redistribute money to make the consumer shopping experience faster and more efficient. While being available to international markets, more products will sell.

24/7, 365 days: If it's snowing and the roads are closed, or it's too hot and humid to even step outside in the summer, or a holiday that every store in town closes, your online business is open for consumers 24/7 every day of the year. The doors never close and profits will keep rising.

Expand business reach: A great tool on the internet is...translation! A business online does not have to make a site for every language. With the right marketing, every consumer around the globe can find the business site, products and information without leaving home.

Recurring payments made easy: With a little research, every business can set up recurring payments. Find the provider that best suits your needs and billing will be done in a consistent manner; payments will be received in the same way.

Instant transactions: With e-commerce there is no more waiting for the check to clear or a 30day wait for certain other types of payment. Transactions are cleared immediately or at most two to three days for the money to clear through the banking system.

\section{E-COMMERCE DISADVANTAGES FOR CUSTOMERS}

Privacy and security: Before making instant transactions online, be sure to check the sites certificates of security. While it may be easy and convenient to shop, no one wants their personal information to be stolen. While many sites are reputable, always do your research for those with less than sufficient security.

Quality: While e-commerce makes everything easily accessible, a consumer cannot actually touch products until they are delivered to the door. It is important to view the return policy before buying. Always make sure returning goods is an option.

Hidden costs: When making purchases, the consumer is aware of the product cost, shipping, handling and possible taxes. Be advised: there may be hidden fees that won't show up on your purchasing bill but will show up on your form of payment. Extra handling fees may occur, especially with international purchases.

Delay in receiving goods: Although delivery of products is often quicker than expected, be prepared for delays. A snow storm in one place may throw off the shipping system across the board. There is also a chance that your product may be lost or delivered to the wrong address. 
Need access to internet: Internet access is not free, and if you are using free wifi, there is the chance of information theft over an unsecure site. If you are wearing of your public library, or cannot afford the internet or computer at home, it may be best to shop locally.

Lack of personal interaction: While the rules and regulations of each e-commerce business is laid out for you to read, there is a lot to read and it may be confusing when it comes to the legalities. With large or important orders, there is no one you can talk to face to face when you have questions and concerns.

\section{E-COMMERCE DISADVANTAGES FOR BUSINESSES}

Security issues: While businesses make great efforts to keep themselves and the consumer safe, there are people out there that will break every firewall possible to get the information they want. We have all seen recently how the biggest and most renowned business can be hacked online.

Credit card issues: Many credit card businesses will take the side of the consumer when there is dispute about billing - they want to keep their clients, too. This can lead to a loss for e-commerce business when goods have already been delivered and the payment is refunded back to the consumer.

Extra expense and expertise for e-commerce infrastructure: To be sure an online business is running correctly, money will have to be invested. As an owner, you need to know transactions are being handled properly and products are represented in the most truthful way. To make sure you get what you need, you will have to hire a professional to tie up any loose ends.

Needs for expanded reverse logistics: The infrastructure of an online business must be on point. This will be another cost to the business because money will need to be invested to ensure proper handling of all aspects of buying and selling, especially with disgruntled consumers that want more than a refund.

Sufficient internet service: Although it seems that everyone is now on the internet all the time, there are still areas in which network bandwidth can cause issues. Before setting up an ecommerce business, be sure your area can handle the telecommunication bandwidth you will need to run effectively.

Constant upkeep: When a business has started as e-commerce, they must be ready to make changes to stay compatible. While technology grows, the systems that support your business must be kept up to date or replaced if needed. There may be additional overhead in order to keep data bases and applications running.

\section{CHALLENGES OF E-COMMERCE IN INDIAN BANKS}

The e-commerce industry in India is growing at a remarkable pace due to high penetration of internet and sophisticated electronic devices. However, the recent growth rate of e-commerce in India is far lagging behind than other developed countries. There are many big problems and challenged on the way of an online merchant. Factors like safety and security of online money 
transaction being the biggest problem along with others have curbed the smooth expansion of the online industry in the country. Although, major portion of e-business sectors have affected by the below mentioned challenges but still there are few online giants like Makemytrip.com, flipkart.com, Snapdeal.com who have overcome the challenges and represents the perfect growth trends of e-commerce in India.

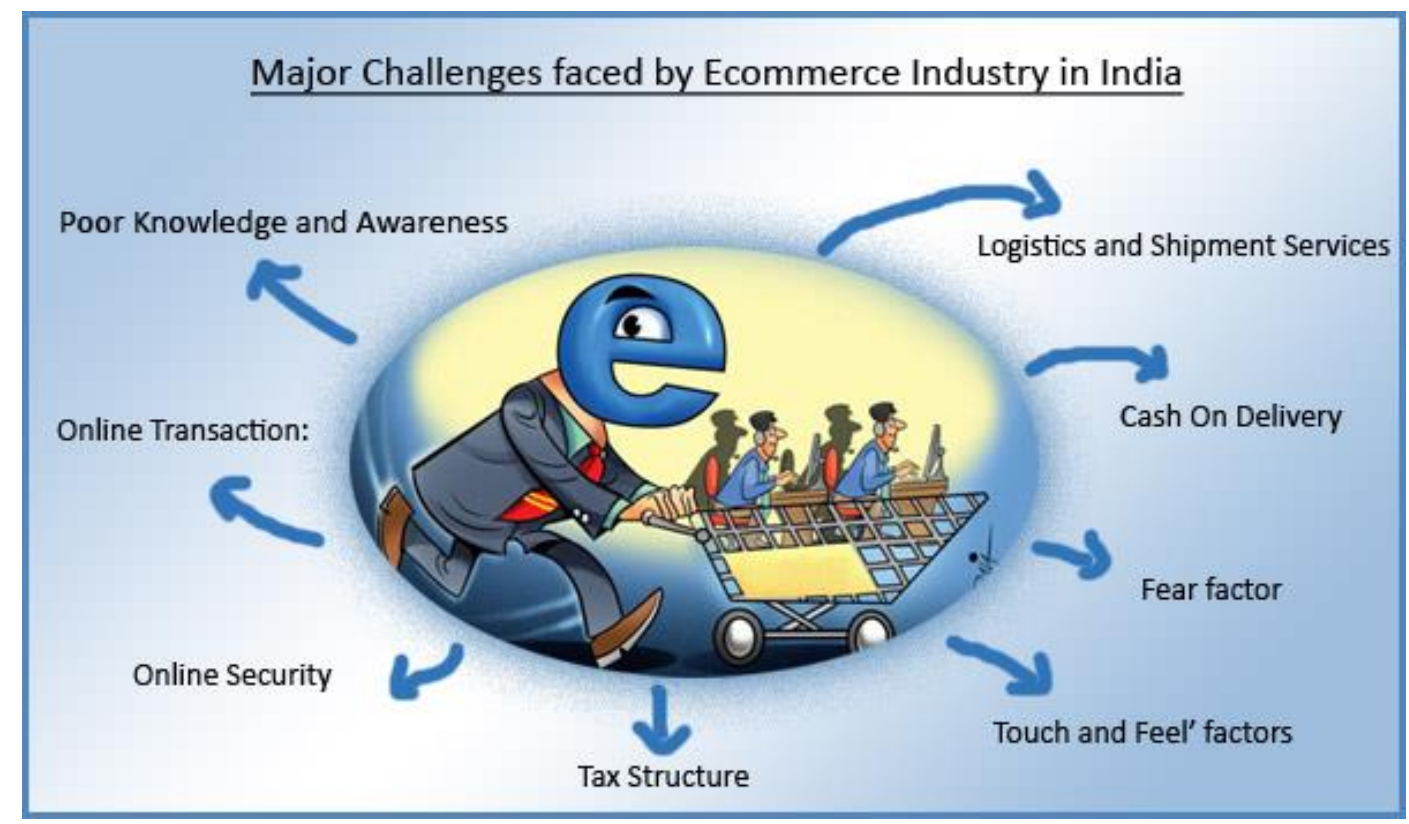

Source: https://media.licdn.com/

Poor Knowledge and Awareness: When it comes to ratio of internet consumers, scenario is not so admirable one. Majority of Indian rural population are unaware of internet and it uses. Surprisingly, most of internet savvies or urban population are also suffering from poor knowledge on online business and its functionalities. Very few are aware of the online corruption and fraud and thus darkness still exists. A reliable survey reveals that $50 \%$ of Indian online users are unaware of the solution of online security.

Online Transaction: Most of Indian customers do not possess plastic money, credit card, debit card and net banking system, which is one of the prime reasons to curtail the growth of ecommerce. Nevertheless, in recent years, some of the nationalized banks have started to issue debit cards to all its account holders. This is undoubtedly a positive sign for Indian online entrepreneurs.

Cash on Delivery: Cash on Delivery (COD) has evolved out of less penetration of credit card in India. Most of Indian E-commerce companies are offering COD as one of mode of payment for the buyers. 30\%-50\% of buyers are also taking advantage of this mode of payment while making purchase of any product and service over internet. COD has been introduced to counter the payment security issues of online transaction, but this mode has been proving to be loss and expensive to the companies. It is seen that majority of the customers denied to make the payment at the time of delivery of the product. Hence, companies tend to lose the sale along with product transit fees. In order to curb the problem of COD, online companies should take some judicial steps; otherwise basic logic behind the ecommerce business will be at risk. 
Online Security: In case of startup and small business, Business owners are ignoring the importance of authentic software due to budget constraints. They are even failing to take the initial steps to secure and protect their online business through installation of authentic protection services like antivirus and firewall protection, which indeed a crucial step for successful online business players. In India, maximum number of business entrepreneurs used unauthorized software in their server, which usually does not come with upgraded online security. Such pirated software leaves room for virus, malwares and Trojan attacks and it is highly risky task to make online transactions in the systems, which may disclose or leak sensitive details of credit cards and online banking of the users. These kinds of droopiness should be banned in Indian ecommerce sectors. Affiliation to SSL certificate should be imposed as a mandatory action for every owner.

Logistics and Shipment Services: In India, logistics and courier services required lots of improvement. While, perfect and strong logistics service is one of the key reasons behind the success of any online company, India is lagging far behind in this sector as most of the town and small villages are still not covered under serviceable area of many of the courier and logistic companies. Ecommerce is hampered in a big way owing to the limited services offered by the courier service companies.

Tax Structure: Tax rate system of Indian market is another factor for lesser growth rate of ecommerce in India in comparison to other developed countries like USA and UK. In those countries, tax rate is uniform for all sectors whereas tax structure of India varies from sector to sector. This factor creates accounting problems for the Indian online business companies.

Fear factor: Fear of making online payment is a universal psychological factor of Indian customers. With the spread of knowledge on online transactions and its reliability, some percentages of customers have overlooked this fear and they are fearlessly engaging themselves in online shopping. But still, majority of customers are not aware of online transactions and its security. They often reluctant to disclose their credit card and bank details and preferred to stay away from online world of shopping.

'Touch and Feel' factors: Indian customers are more comfortable in buying products physically. They tend to choose the product by touching the product directly. Thereby, Indian buyers are more inclined to do ticketing and booking online in Travel sectors, books and electronics. Companies dealing with products like apparel, handicrafts, jewellery have to face challenges to sell their products as the buyers want to see and touch before they buy these stuffs.

\section{CONCLUSION}

Today's digital marketing world, e-commerce plays a vital role in buying behaviour of customer. The e-commerce industry in India is growing at a remarkable pace due to high penetration of internet and sophisticated electronic devices. However, the recent growth rate of e-commerce in India is far lagging behind than other developed countries. There are many big problems and challenges on the way of an online merchant. Factors like safety and security of online money transaction being the biggest problem along with others have curbed the smooth expansion of the online industry in the country. 


\section{REFERENCE}

[1] Golden, S. A. R., \& Regi, S. B. (2015). Satisfaction of Customers towards User Friendly Technological Services offered by Public and Private Sector banks at Palayamkottai, Tirunelveli District. International Journal of Research, 2(3), 775-787.

[2] Golden, S. A. R. (2015). Regional Imbalance affecting quality of e-banking services with special reference to Tuticorin District-An Analysis. International Journal of Research, 2(3), 788-798.

[3] Dr.S.P.Bansal , "Job satisfaction among bank employees. A study of public sector of cooperative banks in Shimla town”, India cooperative review national union of trade India, New Delhi, Jan 2000 Vol.xxxvii, Issue 3, p. 138.

[4] https://media.licdn.com/mpr/mpr/shrinknp_800_800/aaeaaqaaaaaaaaitaaaajdvlotzlymnil ty3ztatndq4zs04mtgxlwm3n2fhywnhm2mxyw.jpg

[5] http://www.enkivillage.com/e-commerce-advantages-and-disadvantages.html

[6] http://www.networksolutions.com/education/what-is-ecommercel 